\title{
Ocular injuries from liquid golf ball cores
}

\author{
D. R. LUCAS, ${ }^{1}$ A. C. DUNHAM, ${ }^{2}$ W. R. LEE, ${ }^{3}$ W. WEIR, ${ }^{4}$ AND \\ F. C. F. WILKINSON ${ }^{2}$ \\ From the Departments of Ophthalmology, ${ }^{1}$, Pathology, ${ }^{1}$ and Geology ${ }^{2}$, University of Manchester, the \\ Department of Ophthalmology, University of Glasgow, ${ }^{3}$ and the Department of Pathology, Royal Alexandra \\ Infirmary, Paisley ${ }^{4}$
}

Cutting up golf balls, usually by children, has long been recognized as an ocular hazard as many golf balls contain fluid under high pressure which is liable to strike the eye (Duke-Elder, 1954). In some of the early cases, serious loss of vision resulted (Crigler, I913; Lowell, 1913; Thomason,

Address for reprints: D. R. Lucas, Department of Ophthalmology, Manchester Royal Eye Hospital, Oxford Road, Manchester Mi3 $9 \mathrm{WH}$, or A. C. Dunham, Department of Geology, Williamson Building, The University, Manchester MI3 9PL, or W. R. Lee, Tennent Institute of Ophthalmology, Western Infirmary, Glasgow GI I 6NT
1913). The early golf balls contained barium sulphate, soap, and free alkali (Crigler, I913). The alkali was presumably responsible for the serious ocular injuries and, after 1914, it was no longer used in the manufacture of golf balls in the United States of America. Barium sulphate is still, however, a major constituent of recently manufactured golf balls, at least in the UK.

Twelve cases of injury to the eyelid, conjunctiva, and orbit resulting from disrupted golf balls have been reported during the last 10 years (Table I).

Table I Published cases of injuries from golf ball contents

\begin{tabular}{|c|c|c|c|c|c|c|}
\hline Authors & Cases & $\begin{array}{l}\text { Age } \\
\text { (years) }\end{array}$ & $\operatorname{Sex}$ & $\begin{array}{l}\text { Time between } \\
\text { injury and } \\
\text { excision }\end{array}$ & Site(s) of injury & Follow-up \\
\hline Johnson and Zimmerman (1965) & $\mathbf{I}$ & I I & Male & I I days & Conjunctiva* & \\
\hline \multirow[t]{2}{*}{ Penner (1966) } & $\mathbf{I}$ & I I & Male & I year & $\begin{array}{l}\text { Lower lid* and } \\
\text { orbit }\end{array}$ & \multirow[t]{2}{*}{$\begin{array}{l}\text { Satisfactory after } \\
\text { excision of mass } \\
\text { one year after } \\
\text { accident }\end{array}$} \\
\hline & 2 & 10 & Female & - & Face, no penetration & \\
\hline \multirow[t]{4}{*}{ Slusher and others (1967) } & $\mathbf{I}$ & II & Male & 5 days & $\begin{array}{l}\text { Conjunctiva* and } \\
\text { cornea }\end{array}$ & \multirow{4}{*}{$\begin{array}{l}\text { Satisfactory after } \\
\text { excision } \\
\text { Satisfactory after } \\
\text { removal of pasty } \\
\text { material by } \\
\text { applicator } \\
\text { Satisfactory after } \\
\text { excision }\end{array}$} \\
\hline & 2 & 15 & Male & Hours & Conjunctiva ? & \\
\hline & 3 & 12 & Male & Hours & $\begin{array}{l}\text { Conjunctiva and } \\
\text { cornea }\end{array}$ & \\
\hline & 4 & 9 & Male & Hours & $\begin{array}{l}\text { Conjunctiva and } \\
\text { cornea }\end{array}$ & \\
\hline \multirow[t]{2}{*}{ Taylor and Greer (1969) } & $\mathbf{I}$ & 12 & Male & 6 months & Conjunctiva* & \multirow{2}{*}{$\underline{\text { Uneventful }}$} \\
\hline & 2 & 12 & Female & 6 weeks & $\begin{array}{l}\text { Conjunctiva* and } \\
\text { cornea }\end{array}$ & \\
\hline \multirow[t]{2}{*}{ Nelson (1970) } & $\mathbf{I}$ & 22 & Male & Not stated & $\begin{array}{l}\text { Conjunctiva and } \\
\text { cornea }\end{array}$ & \multirow[t]{2}{*}{$\begin{array}{l}\text { Traumatic mydriasis } \\
9 \text { months after } \\
\text { accident }\end{array}$} \\
\hline & 2 & $3 \mathbf{I}$ & Male & Not stated & Cornea & \\
\hline O'Grady and Shoch (1973) & $\mathbf{I}$ & 13 & Female & 2 months & Conjunctiva* & Uneventful \\
\hline
\end{tabular}


Table II Details of nine cases

\begin{tabular}{|c|c|c|c|c|c|c|}
\hline Case & $\begin{array}{l}\text { Age } \\
\text { (years) }\end{array}$ & $\operatorname{Sex}$ & $\begin{array}{l}\text { Injury to } \\
\text { excision } \\
\text { period }\end{array}$ & Nature of explosion & Site & Follow-up \\
\hline $\mathbf{I}$ & 12 & Male & I 8 hours & Disruption of golf ball & Subconjunctiva & Uneventful \\
\hline 2 & 8 & Male & $<48$ hours & $\begin{array}{l}\text { Stuck a knife into a } \\
\text { golf ball }\end{array}$ & $\begin{array}{l}\text { Right supero-nasal } \\
\text { bulbar conjunctiva }\end{array}$ & Pseudopterygium \\
\hline 3 & I I & Female & $<48$ hours & $\begin{array}{l}\text { Hacksaw used to open } \\
\text { golf ball in a vice }\end{array}$ & $\begin{array}{l}\text { Xanthelasma-like } \\
\text { lesion left upper } \\
\text { eyelid with deposit } \\
\text { in fornix }\end{array}$ & $\begin{array}{l}\text { Severe oedema of lid. } \\
\text { Residual scar. Inter- } \\
\text { mittent conjunctivitis }\end{array}$ \\
\hline 4 & 12 & Male & 5 days & Cutting into golf ball & $\begin{array}{l}\text { Small white mass in } \\
\text { left supero-temporal } \\
\text { conjunctiva. } \\
\text { Commotio retinae }\end{array}$ & $\begin{array}{l}\text { Uneventful } \\
\text { Chorioretinal scar }\end{array}$ \\
\hline 5 & 12 & Female & 6 days & $\begin{array}{l}\text { Stuck a knife into a } \\
\text { golf ball }\end{array}$ & $\begin{array}{l}\text { Inferior bulbar } \\
\text { conjunctiva }\end{array}$ & Uneventful \\
\hline 6 & $\mathbf{1 3}$ & Male & 7 days & $\begin{array}{l}\text { Focused sun's rays on } \\
\text { a golf ball }\end{array}$ & $\begin{array}{l}\text { Supero-nasal bulbar } \\
\text { conjunctiva* } \\
\text { Eyelid }\end{array}$ & Uneventful \\
\hline 7 & I0 & Male & I 8 days & Cut up golf ball & $\begin{array}{l}\text { Right bulbar con- } \\
\text { junctiva three } \\
\text { nodules in substantia } \\
\text { propria on nasal side }\end{array}$ & $\begin{array}{l}\text { Betamethasone } \\
\text { a }\end{array}$ \\
\hline 8 & 13 & Male & I6 weeks & Cut up golf ball & $\begin{array}{l}\text { Black deposits in left } \\
\text { supra-bulbar } \\
\text { conjunctiva }\end{array}$ & Uneventful \\
\hline 9 & I I & Male & 20 weeks & $\begin{array}{l}\text { Golf ball 'exploded' in } \\
\text { face }\end{array}$ & $\begin{array}{l}\text { Punctate staining of } \\
\text { cornea; sub- } \\
\text { conjunctival white } \\
\text { mass on lower } \\
\text { temporal bulbar } \\
\text { conjunctiva }\end{array}$ & Small residual nodule \\
\hline
\end{tabular}

*Blanching of the conjunctiva in upper nasal quadrant looked like a local corticosteroid injection

Most of the injured were boys, aged between 10 and 13 years. Histological studies of six cases (Johnson and Zimmerman, 1965; Penner, 1966; Slusher, Jaegers, and Annesley, 1967; Taylor and Greer, 1969; O'Grady and Shoch, 1973) revealed birefringent granules with multinucleate giant cells and macrophages. In three cases (Johnson and Zimmerman, 1965; O'Grady and Shoch, 1973) analysis of the foreign material by histochemistry, $x$-ray diffraction, and the electron probe demonstrated the presence of barium sulphate and zinc sulphide.

The opportunity to study a further nine cases has permitted a more detailed analysis of the tissue response between 18 hours and 20 weeks. In addition, the foreign material in some of the specimens has been studied by applying the electron probe to thick paraffin sections of the biopsied material and, for comparative purposes, the contents of several brands of golf ball have also been analysed.

\section{Methods}

\section{LIGHT MICROSCOPICAL EXAMINATION}

The tissue was prepared by conventional histological methods.

\section{ELECTRON PROBE ANALYSIS}

20- $\mu \mathrm{m}$ sections were cut from the paraffin blocks from which the sections for light microscopical examination 


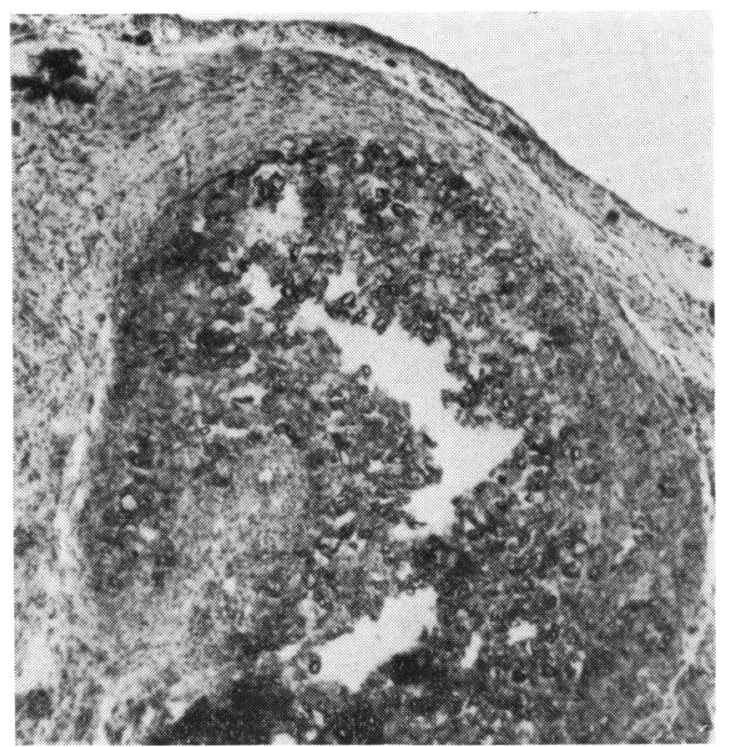

( $\mathrm{a} a)$

FIG. I Conjunctiva 18 hours after accident (Case I). (a) Large zuell circumscribed deposit of crystalline material in substantia propria. Haematoxylin and eosin. $\times 50$. (b) Pyknotic debris around the deposit. Haematoxylin and eosin. $\times 25^{\circ}$

had already been taken. These were mounted on glass slides $5.1 \times 2.5 \mathrm{~cm}(2 \times 1$ in) and coated with carbon after removal of the wax. The samples were investigated using a Cambridge Scientific Instruments Geoscan Mark II.

$x$-RAY DIFFRACTION AND $x$-RAY FLUORESCENCE OF GOLF BALL CONTENTS

The slurry from the centres of nine different types of golf ball was extracted using a hypodermic syringe. In several cases the pressure of the slurry was enough to force the piston right out of the syringe. The slurry was then dried and the solid residue examined by transmitted and reflected light techniques and by $x$-ray diffraction. Smear mounts of the dried slurry were examined in a Phillips diffractometer.

Semiquantitive analysis of two dried slurries was made using a Phillips $x$-ray fluorescence machine.

\section{Cases}

Details of the nine cases are set out in Table II. In all cases, conjunctival lesions were present; in two (Cases 3 and 6) the eyelid was also involved. In Case 8 the deposits were black, but in all others they were creamywhite.

In five cases, there was complete and uneventful

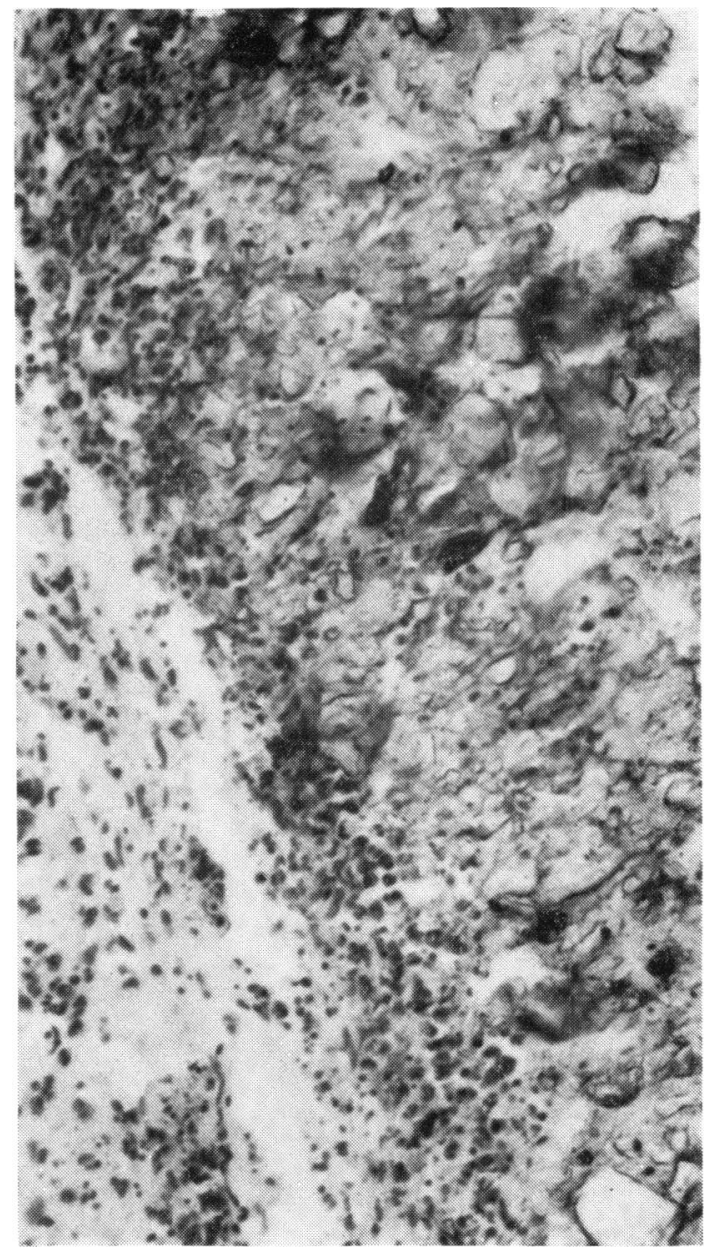

( $\mathrm{a} b)$

recovery after local excision, but residual scarring occurred in the other four. In one of these (Case 7) treatment with betamethasone was required. No significant loss of vision occurred in any case, although a small patch of commotio retinae which healed with a small chorioretinal scar was noted in Case 4.

\section{Histological appearances}

I 8 TO 48 HOURS

The deposits of crystalline material and other foreign matter were present in large pools in the substantia propria of the conjunctiva, in the dermis, and in the orbicularis muscle. These pools contained some necrotic debris and red cells and were surrounded by a thin rim of polymorphs and lymphocytes. Many of these cells showed nuclear pyknosis and numerous free nuclear fragments were also present (Fig. I). In one (Case 3) birefringent material was observed in macrophages. The Prussian blue reaction demonstrated some ironcontaining crystalline material in the debris. 


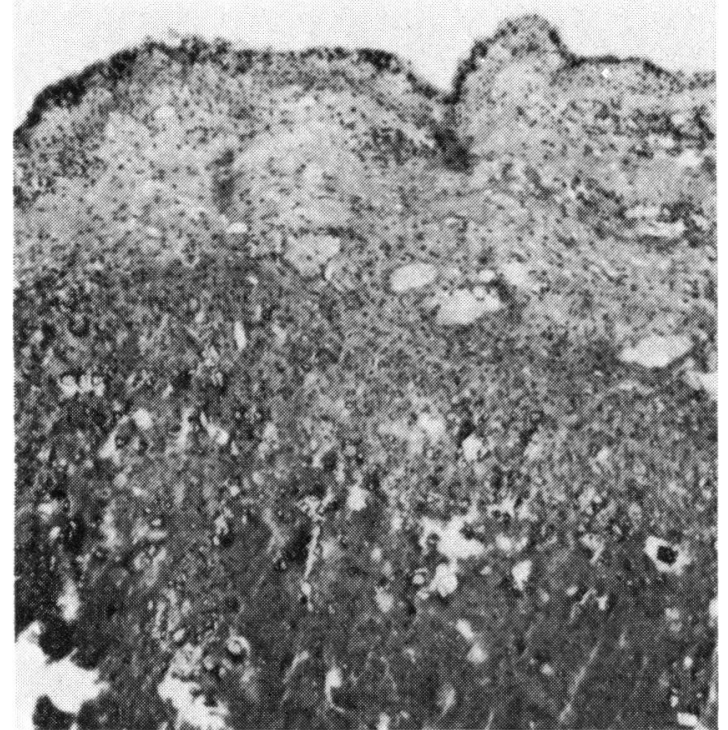

(2a)

FIG. 2 Conjunctiva five days after accident (Case 4). (a) Deposit of crystalline material in substantia propria surrounded by a well defined layer of macrophages. Haematoxylin and eosin. $\times 50$

(b) Palisade-like arrangement of crystal-containing macrophages in the layer. Haematoxylin and eosin. $\times 250$

\section{TO I 8 DAYS}

In the four cases in this group, the centre of the deposit still contained amorphous necrotic debris around the birefringent material. At the periphery, there was a cellular infiltrate composed predominantly of lymphocytes and macrophages. The macrophages formed a distinctive palisade between the deposit and adjacent tissue in three cases $(4,5$, and 7 , Fig. 2). In the eyelid tissue from Case 6 , the cellular reaction was particularly diffuse, presumably because the crystals were widely scattered in the dermis. Very small crystals were observed in the cytoplasm of the macrophages while the larger crystals were surrounded by small flattened multinucleate cells (Fig. 3). Even at this stage, perivascular accumulations of macrophages containing birefringent crystals could be seen.

Palisading of macrophages was prominent in the 18-day specimen.

\section{I6 TO 20 WEEKS}

The crystalline and other foreign matter was embedded in a delicate fibrovascular stroma to form a clearly circumscribed mass in the 16-week specimen (Fig. 4a). In this case many black particles were present. Numerous macrophages and multinucleate giant cells were present in the stroma and strands of histiocytes containing small particles were seen lying along small blood vessels (Fig. 4).

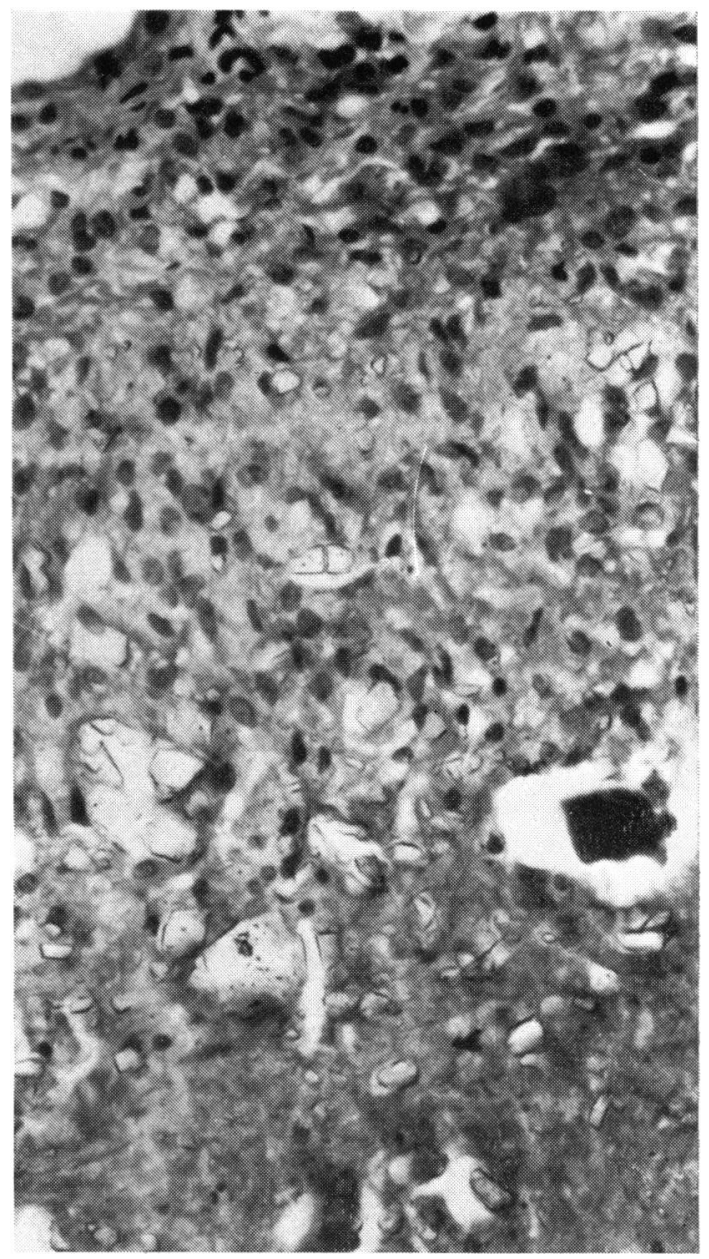

(2b)

The 20-week specimen contained numerous multinucleate giant cells.

\section{Analysis of the foreign material in tissue sections}

The foreign material consisted principally of clear or pale-staining birefringent crystals varying considerably in size in different specimens (Figs $\mathrm{I}-4 b$ ). In addition, semi-opaque brownish-black particles varying in size and shape were present. The amount of this material differed greatly in different specimens. Some contained hardly any, while in Case 8 the amount was sufficient to account for the almost black appearance of the deposits.

The birefringent crystals were frequently almost square (rhombic, angles $80^{\circ}$ and $110^{\circ}$ ) (for example, Figs $\mathrm{I}$ and $2 b$ ). Under crossed polars the extinction position indicated that the principal optical directions lay along the diagonals of the rhomboid 


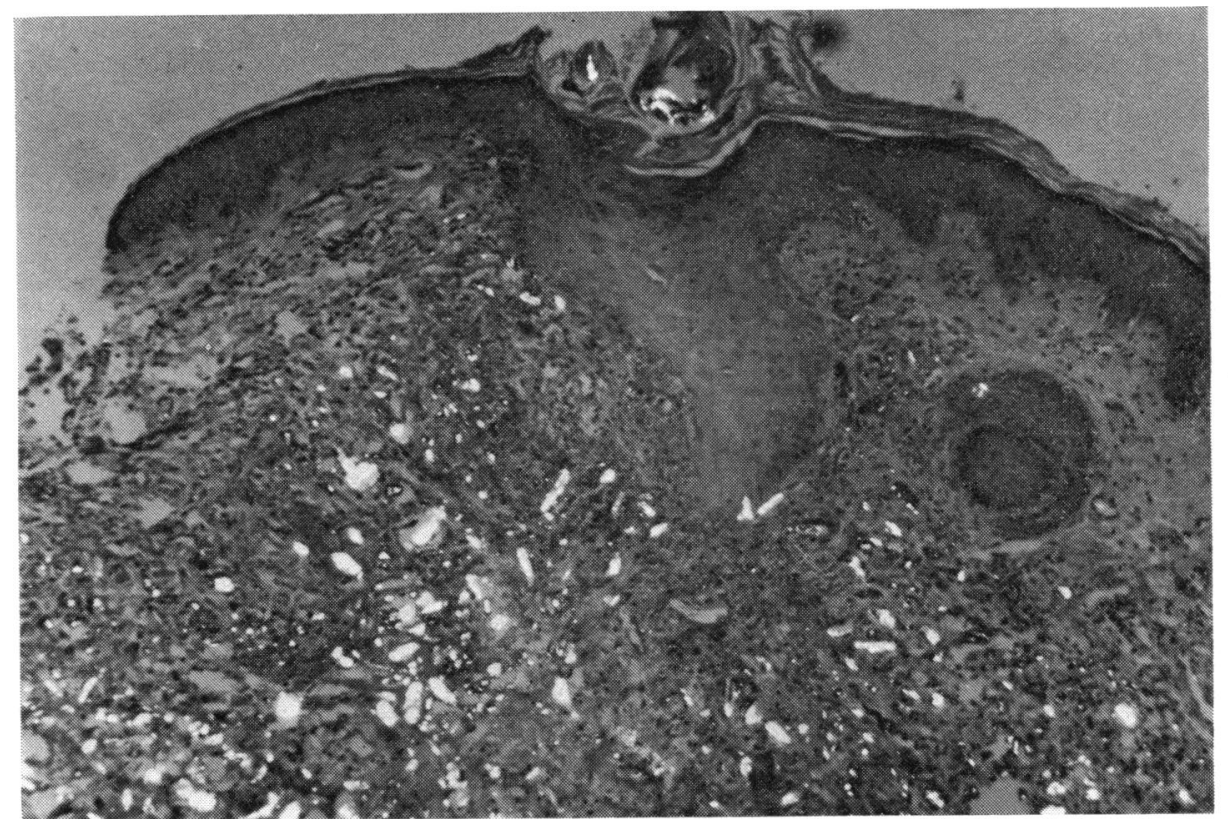

(3a)

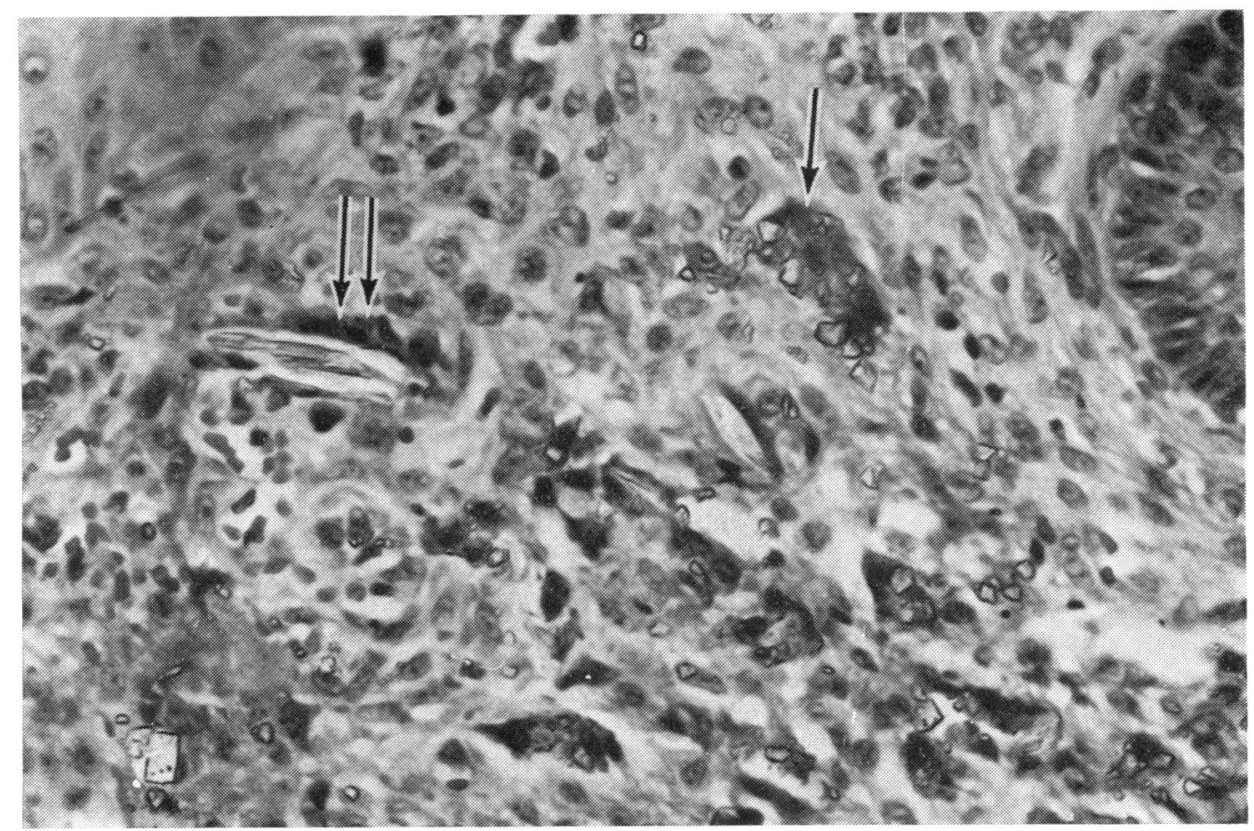

(3b)

FIG. 3 Eyelid seven days after accident (Case 6).

(a) Diffusely scattered crystals in the dermis. Haematoxylin and eosin. $\times 50$, under polarized light. (b) Light diffuse infiltration of dermis with inflammatory cells, giant cells containing small crystals (single arrow) and flattened giant cells around large crystals (arrows). Haematoxylin and eosin. $\times 250$ 


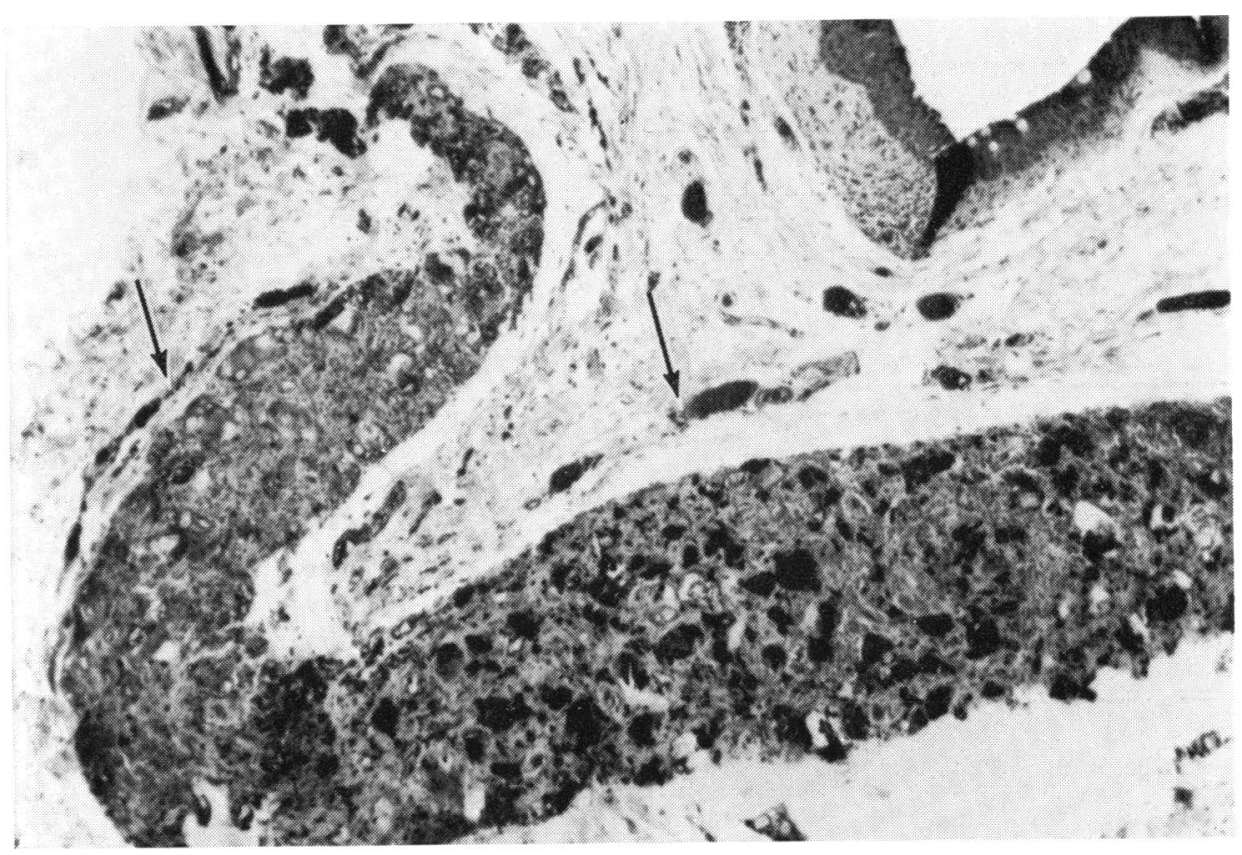

$(4 a)$

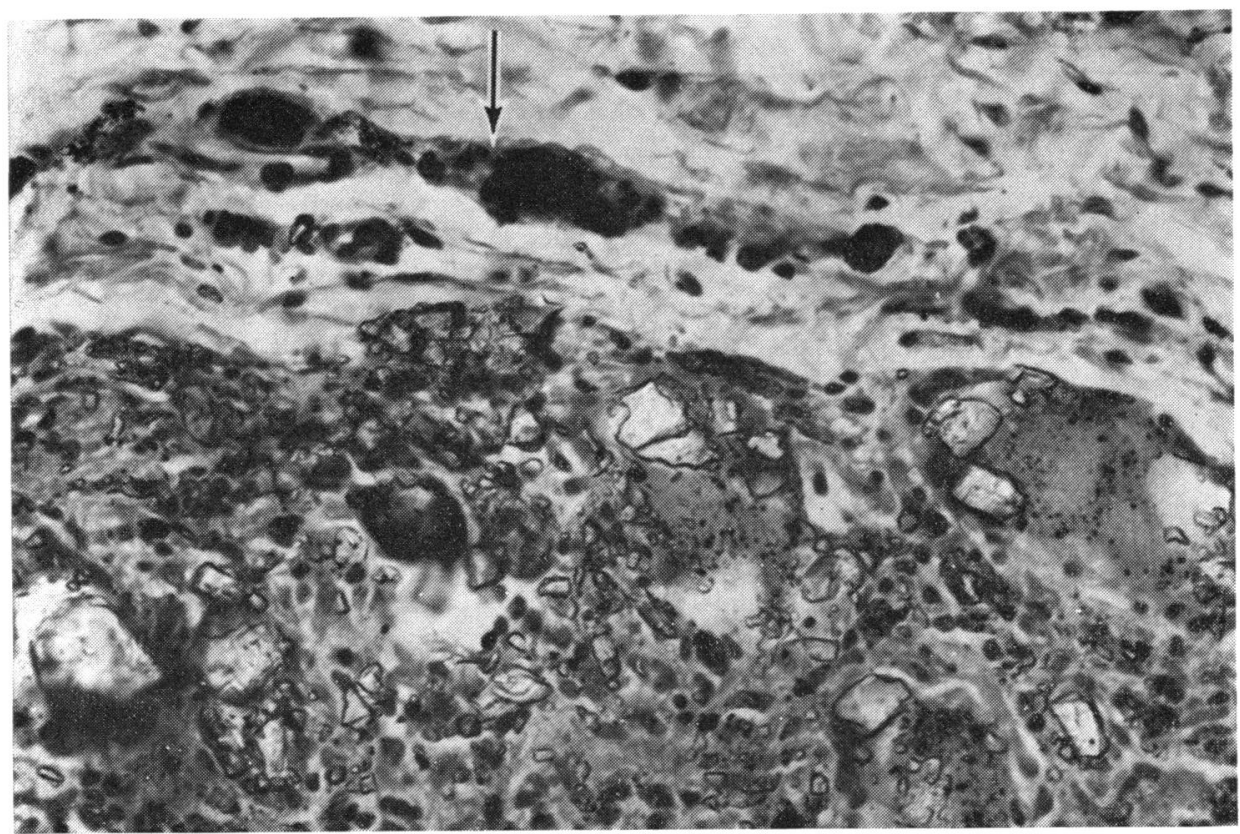

$(4 b)$

FIG. 4 Conjunctiva 16 weeks after accident (Case 8).

(a) Deposits of crystalline and black material in substantia propria embedded in fibrovascular stroma. Strands of macrophages laden with foreign material present along blood vessels (arrows). Haematoxylin and eosin. $\times 50$.

(b) Macrophagic reaction in stroma and perivascular macrophages containing foreign material (arrows). Haematoxylin and eosin. $\times 250$ 
Table III Partial electron probe analysis of barytes

\begin{tabular}{|c|c|c|c|}
\hline & \multicolumn{3}{|c|}{ Pulses/unit time for barytes* } \\
\hline & \multirow{2}{*}{ Case 3} & \multicolumn{2}{|l|}{ Case 5} \\
\hline & & Block I & Block 2 \\
\hline Barytes standard & 8745 & 3673 & 8745 \\
\hline Sample & 7496 & $356 \mathrm{I}$ & 8634 \\
\hline
\end{tabular}

Table IV Comparison of electron probe analysis of dark particles in Case 8 with published composition of hydromuscovite and muscovite (Deer, Howie, and Zussman, 1966)

\begin{tabular}{|c|c|c|c|}
\hline Dark particles & Case 8 & Hydromuscovite & Muscovite \\
\hline $\mathrm{SiO}_{2}$ & $46 \cdot 7$ & $46 \cdot 5$ & $48 \cdot 4$ \\
\hline $\mathrm{Al}_{2} \mathrm{O}_{3}$ & $33 \cdot 9$ & $36 \cdot 4$ & $27 \cdot 2$ \\
\hline $\mathrm{K}_{2} \mathrm{O}$ & 10.7 & $8 \cdot I$ & I $1 \cdot 2$ \\
\hline Fe Oxide & $2 \cdot 6^{*}$ & $0.7 t$ & $7 \cdot 4 t$ \\
\hline $\mathrm{MgO}$ & Present & 0.5 & 0.0 \\
\hline $\mathrm{Na}_{2} \mathrm{O}$ & Present & 0.5 & 0.4 \\
\hline $\mathrm{H}_{2} \mathrm{O}$ & Not known & n 6.8 & $4 \cdot 5$ \\
\hline$\Sigma$ & $93 \cdot 9$ & $99 \cdot 5$ & $99 \cdot 1$ \\
\hline
\end{tabular}

shapes. The optical data indicate that the crystals are crushed barytes $\left(\mathrm{BaSO}_{4}\right)$, whose shape is controlled by cleavage along the $(210)^{*}$ faces.

Quantitative microprobe analysis by the use of the crystal spectrometers (Table III) showed that barytes was the major constituent of the foreign material ( $>90$ per cent).

The semi-opaque, brownish-black particles often appeared hexagonal (Fig. 4a). They were much thinner than the section of tissue $(20 \mu \mathrm{m})$ and showed very low birefringence which, in some cases, was masked by the dark brown colour. Microprobe analysis proved the particles to be muscovite or hydromuscovite (Table IV).

A single grain of pyrite and several grains of iron oxide were found in Case 8 by microprobe analysis.

No zinc-bearing grains were detected.

\section{Analysis of golf balls}

Eight out of the nine slurries from the centre of the balls were white, while the ninth was black. Microscopical examination of the dried slurries showed the presence of large amounts of barytes, with shapes and sizes very similar to those found in the granulomata. The dark hexagonal grains were also present in small quantities. The darkcoloured slurry differed only in having a darkcoloured fluid medium.

$X$-ray diffraction charts of all nine samples were identical; the only mineral showing up in the trace was barytes. This suggests that the muscovite may be poorly crystalline and hence would not produce $x$-ray diffraction. The amount of the muscovite is also small ( $\sim 5$ per cent). Partial $x$-ray fluorescence analyses of two samples were made. These were very similar except for the content of $\mathrm{Sr}$ (Table V) which is no doubt related to the source of the barytes used by the different manufacturers. The $\mathrm{Pb}$ reported in the analysis is probably present as galena $(\mathrm{PbS})$.

\section{Discussion}

Most golf balls manufactured in this country still contain a liquid centre under high pressure. The particulate material in the liquid is capable of penetrating both conjunctiva and skin if the rubber casing of the liquid centre is perforated by the unwary. The mineral assemblage found in this material and in the tissue sections from those injured (barytes, muscovite, galena, pyrite, and iron oxide) is typical of natural barytes deposits. The barytes was in the form of crushed crystals. In the American cases, the crystalline material was apparently barium sulphate and zinc sulphide (Johnson and Zimmerman, 1965; O'Grady and Shoch, 1973) and the birefringent crystals were white in unstained sections, and the lesions did not appear to be pigmented grossly. The material was thought to have been derived from lithopone, which is a mixture composed of 70 per cent $\mathrm{BaSO}_{4}$ and 30 per cent $\mathrm{ZnS}$, but Johnson and Zimmerman ( 965 ) failed to identify zinc by $x$-ray microanalysis.

Table V $X$-ray fluorescence analysis of dried slurry from a Dunlop 65 golf ball

\begin{tabular}{|c|c|}
\hline $\mathrm{SiO}_{2}$ & $5 \cdot 8$ \\
\hline $\mathrm{Al}_{2} \mathrm{O}_{3}$ & $2 \cdot 8$ \\
\hline $\mathrm{FeO}$ & 0.4 \\
\hline $\mathrm{MgO}$ & $0 \cdot 1$ \\
\hline $\mathrm{CaO}$ & 0.1 \\
\hline $\mathrm{Na}_{2} \mathrm{O}$ & $<0.1$ \\
\hline $\mathrm{K}_{2} \mathrm{O}$ & $0 \cdot 1$ \\
\hline $\mathrm{Sr}$ & $0.28(1.00) *$ \\
\hline $\mathrm{Pb}$ & $1 \cdot 00$ \\
\hline $\mathrm{Zn}$ & $0 \cdot 1$ \\
\hline $\mathrm{Ti}$ & 0.1 \\
\hline Mn & $\ll 0.1$ \\
\hline $\mathbf{B a}$ & Abundant \\
\hline $\mathbf{S}$ & Abundant \\
\hline
\end{tabular}

*Penfold Club b all 
They attributed the failure of matrix effect in the sample to the large mass absorption coeff.cient of $\mathrm{Ba}$. However, in experiments with a mixture of 30 per cent $\mathrm{ZnS}$ and 70 per cent $\mathrm{BaSO}_{4}$ (Dunham and Wilkinson, unpublished) in which an $x$-ray diffractometer rather than a powder camera was used, it was found that, of the four principal $x$-ray peaks shown by $\mathrm{ZnS}$, three were coincident or very close to the $\mathrm{BaSO}_{4}$ peaks, but the fourth was quite distinct. The matrix effect did not mask the $\mathrm{ZnS}$.

Sections from Johnson and Zimmerman's material were subjected to electron probe $x$-ray microanalysis and zinc was detected in addition to barium and sulphur (Johnson and Zimmerman, 1965).

Doubt thus remains as to the exact identity of the crystalline material in the American cases, although the major ingredient was, as in our cases, $\mathrm{BaSO}_{4}$. The brown or black particles in our cases were separate mineral particles which electron probe analysis showed to be of the mica group. Zinc was present only in trace quantities.

The histological response of the tissues to $\mathrm{BaSO}_{4}$ crystals differs in some respects in our cases from previous accounts. In cases examined within a few days of injury, we observed a mild inflammatory response as described by Johnson and Zimmerman (1965) and Slusher and others (1967), but not the distension of macrophages by small particles emphasized by these authors. Within a few weeks, evidence of inflammation and tissue necrosis had disappeared and there was progressive tissue fibrosis. Comparable changes were observed by Penner (1966) and Taylor and Greer (1969). However, no previous mention has been made of the macrophage migration to adjacent blood vessels which was presumably part of an ineffectual attempt to remove foreign material.

An interesting feature of the condition is the great variation in the interval between occurrence of the accident and the appearance of the patient for treatment. This may depend on the intensity of the immediate conjunctival reaction. This reaction probably depends on the nature of the organic binding material which is always present in the golf ball centres and which we have not attempted to identify.

Deposition of crystals in the cornea occurred in six of the 12 published cases. In three there was transient loss of vision (Slusher and others, 1967) and in two there was significant residual disability (Nelson, 1970). In our cases, significant corneal damage was not recorded. Since the cornea represents a large centrally situated area to which the trajectory of the particles must approximate most closely to the perpendicular and thus favour penetration, it is surprising that corneal damage is not a regular feature. The resistance of the cornea may be due to tight epithelial adhesion to Bowman's membrane, the mechanical strength of which probably prevents deep penetration. The substantia propria of the conjunctiva and the dermis of the eyelid are, by contrast, lax tissues.

Finally, the study has demonstrated the relative ease with which individual mineral particles can be identified by means of the electron probe in thick paraffin tissue sections.

\section{Summary}

Tissue removed from nine new cases from 18 hours to 20 weeks after injury by a golf ball contained crystalline and other foreign material to which there was a mild inflammatory reaction followed by macrophagic activity and fibrosis.

Optical and electron probe analysis showed that the crystalline material was crushed barytes containing small quantities of muscovite as is typical in natural deposits. The centres of several golf balls were shown to contain essentially identical material. By contrast with previous reports, no zinc sulphide was found.

The form and frequent location of the deposits in the conjunctiva as compared with cornea and eyelid is related to the structure of these tissues.

We thank the ophthalmic surgeons in the Glasgow and Manchester regions for permission to publish clinical details of their cases and Mr D. Bradley and Mr G. Humberstone for skilled technical assistance in the preparation of the thick sections and the illustrations.

\section{References}

Crigler, L. W. (I913) F. Amer. med. Ass., 6o, i 297

DEER, W. A., HOWIE, R. A., and zUSSMAN, J. (1966) 'An Introduction to Rock-Forming Minerals', p. 23.

Longmans Green, London

DUKE-ELDER, S. (1954) 'Text-Book of Ophthalmology', vol. VI, p. 6582. Kimpton, London

johnson, f. B., and zimmerman, L. E. (1965) Amer. F. clin. Path., 44, 533

lowell, h. (r913) F. Amer. med. Ass., 6r, 2303

NELSON, C. (1970) Brit. F. Ophthal., 54, 670

o'GRADY, R., and SHOCH, D. (1973) Amer. F. Ophthal., 76, I 48

PENNER, R. (1966) Arch. Ophthal. (Chic.), 75, 68

SLUSher, M. M., JAEgers, K. R., and ANNESLEy, w. H. (1967) Amer F. Ophthal., 64, 736

TAYLOR, J. N., and Greer, C. H. (1969) Med. F. Aust., r, 632

thomason, h. e. (r913) F. Amer. med. Ass., 6r, 965 